\title{
Abolition of criminal defamation and retention of scandalum magnatum in Lesotho
}

\section{Hoolo 'Nyane*}

Associate Professor and Head of Department of Public and Environmental Law, School of Law, University of Limpopo, South Africa

https://orcid.org/0000-0001-5674-8163

\section{Summary}

The Constitutional Court of Lesotho in the case of Peta v Minister of Law, Constitutional Affairs and Human Rights struck down the provisions of the Penal Code relating to criminal defamation on the basis that they violate the right to freedom of expression as envisaged in section 14 of the Constitution. The purpose of this article is to analyse the ramifications of the abolition. The article contends that while the boldness of the Constitutional Court is lauded, the commitment of Lesotho to join the global abolitionist movement is doubtful as the vestige of scandalum magnatum remains on the statute books. As such, the country may have to undergo a comprehensive review of the laws hampering the full realisation of freedom of expression, including the Constitution itself. After analysing the key cases on criminal defamation and other 'insult crimes', the article recommends that all 'insult criminal laws' be repealed. The cases studied show that these crimes invariably have been used selectively to protect the 'good image' of people with political status, not ordinary citizens. The article analyses the development of criminal defamation in Lesotho and its 'partial' abolition through the Peta case, and discusses how Lesotho's judicial abolition of criminal defamation features in the broader global wave of abolition.

Key words: Lesotho; abolition; criminal defamation; scandalum magnatum; freedom of expression; Constitution of Lesotho 


\section{Introduction}

The crime of defamation has formed part of Lesotho's common law since 1884 when the country was removed from the administration of the Colony of the Cape of Good Hope. ${ }^{1}$ At the time, the law that was to be applicable in Lesotho was to be the law that 'as nearly as the circumstances of the country will permit, [would] be the same as the law for the time being in force in the Colony of the Cape of Good Hope'$^{2}$ The common law that was applicable in the Cape was the Roman-Dutch common law, ${ }^{3}$ and was to be applicable in Lesotho, despite the resumption of direct rule over Lesotho (then Basutoland) by Britain. ${ }^{4}$ When the country gained independence in 1966 the common law of the country remained the same, and remains so under the current Constitution. ${ }^{5}$ The crime of criminal defamation thus has been part of Lesotho's criminal law ever since Roman-Dutch Law was received as the common law of Lesotho in 1884. However, it was not commonly used until recently. The crime of insult against the authorities that was common in Lesotho since independence was the crime of sedition, ${ }^{6}$ which often was used by politicians in government against other politicians in opposition or any perceived detractor of government, ${ }^{7}$ and was so despite the fact that the Independence Constitution envisaged the right to freedom of expression. ${ }^{8}$ The crime of sedition became popular in Lesotho even under the new Constitution of 1993. During all this time the entire criminal law in Lesotho was uncodified. It was not until 2010 that the country enacted the Penal Code, which codified the entire criminal common law of the country, including criminal defamation and other 'insult offences', namely, sedition, crimen injuria and offences against the royal family (scandalum magnatum). ${ }^{9}$ Similarly, this codification and

1 JE Beardsley 'The common law in Lesotho' (1970) 14 Journal of African Law 198; SM Poulter 'The judicial system of Lesotho' (1970) 3 Comparative and International Law Journal of Southern Africa 63; WCM Maqutu \& AJGM Sanders 'The internal conflict of laws in Lesotho' (1987) 20 Comparative and International Law Journal of Southern Africa 377; AJGM Sanders Internal conflict of laws in South Africa (1990) 21.

2 Sec 2 General Law Proclamation 2B of 1884; see also S Poulter 'The common law in Lesotho' (1969) 13 Journal of African Law 127.

3 IH Pain 'The reception of English and Roman Dutch law in Africa with reference to Botswana, Lesotho and Swaziland' (1978) 11 Comparative and International Law Journal of Southern Africa 137.

4 LBBJ Machobane 'Perceptions on the constitutional future for the Kingdom of Lesotho' (1988) 26 Journal of Commonwealth and Comparative Politics 185.

5 See the Constitution of Lesotho, 1993.

6 Sedition Proclamation 44 of 1938; see also $R v$ Monyau C of A (CRI) 11/04, https:/ /lesotholii.org/ls/judgment/high-court/2005/88 https://lesotholii.org/node/2015 (accessed 1 November 2018); Molapo v R (1999-2000) LLR-LLB 316.

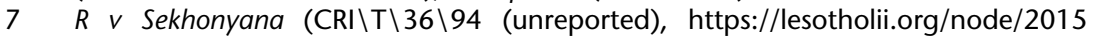
(accessed 1 November 2018).

8 Lesotho Constitution, 1966.

9 See sec 2 of Penal Code Act 6 of 2010. 
retention of 'insult offences', as they were under common law, took place despite section 14(1) of the new Constitution, which provides:

Every person shall be entitled to, and (except with his own consent) shall not be hindered in his enjoyment of, freedom of expression, including freedom to hold opinions without interference, freedom to receive ideas and information without interference, freedom to communicate ideas and information without interference (whether the communication be to the public generally or to any person or class of persons) and freedom from interference with his correspondence.

After 1993 the crime of defamation has been used sparingly. ${ }^{10}$ It was not until 2018 that the Constitutional Court division of the High Court of Lesotho in the case of Peta $v$ Minister of Law, Constitutional Affairs and Human Rights ${ }^{11}$ struck down the criminal defamation provisions in the Penal Code ${ }^{12}$ on the basis that they violated section 14(1) of the Constitution. This decision has been widely received internationally as a positive step for the country towards the implementation of the global call for states to abolish the crime of defamation. ${ }^{13}$ The government had an opportunity to appeal the decision to the Court of Appeal but elected not to do so, thereby yielding to the pressure to join the emerging abolitionist movement.

However, this judicial abolition of the crime of defamation in Lesotho is not complete while scandalum magnatum - the crime of defaming the King - and other insult crimes remain on the statute books. In fact, historically and philosophically, scandalum magnatum is the doctrinal foster-mother of criminal defamation. ${ }^{14}$ From its conception, the crime was intended to protect the reputation of kings and the nobility. ${ }^{15}$ Thus, rather than being a remedy for reputational damage - which is an aspect of human dignity - it was intended to protect the good image of the nobility. Under the Lesotho Penal Code, ${ }^{16}$ the crime of defamation and the scandalum magnatum (offences against the royal family) are created separately. ${ }^{17}$ The Court in the case of Peta abolished only the former; the latter remains on the

10 It was used mainly in those isolated cases at magistrate's court level where the government was persecuting its perceived detractors.

11 CC11/2016 (unreported, decided on 18 May 2018), https://lesotholii.org/ls/ judgment/high-court-constitutional-division/2018/3-0 (accessed 11 November 2018).

12 Act 6 of 2010.

13 Committee to Protect Journalists (CPJ) 'Lesotho Constitutional Court declares criminal defamation unconstitutional' 22 May 2018, https://cpj.org/2018/05/ lesotho-constitutional-court-declares-criminal-def.php; Southern African Litigation Centre (SALC) 'Lesotho: Challenging the offence of criminal defamation' 21 May 2018, http://www.southernafricalitigationcentre.org/2018/05/21/lesotho-challeng ing-the-offence-of-criminal-defamation/ (accessed 20 April 2019).

14 VV Veeder 'The history and theory of the law of defamation' (1903) 3 Columbia Law Review 546.

15 DM Loades 'The theory and practice of censorship in sixteenth century England' (1974) 24 Transactions of the Royal Historical Society 141.

16 Act 6 of 2010.

17 Sec 79 of the Penal Code, 2010. 
statute books and the government has started using it against its detractors. This article contends that while the boldness of the Constitutional Court in striking down criminal defamation is lauded, the commitment of Lesotho as a country to join the global abolitionist movement is doubtful if the vestige of scandalum magnatum is retained on the statute books. The purpose of the article, therefore, is to analyse the development of the crime of defamation in Lesotho and its 'partial' abolition and how the abolition features in the broader global wave of abolition. The argument is anchored mainly in three parts, namely, the investigation into the origins and philosophy of criminal defamation, its application and abolition in Lesotho and the global patterns regarding the crime. Ultimately, the article contends that if Lesotho really intends to join the soaring abolitionist movement at global level, it must follow the total abolition route of crimes aimed at selectively protecting the 'good image' of certain people, such as the royal family.

\section{Changing theoretical and philosophical approaches to criminal defamation}

\subsection{Classical approach}

Defamation, in general, and criminal defamation, in particular, always have been a controversial subject that acquired varying theoretical and philosophical justifications dating from one historical epoch to another. ${ }^{18}$ The approaches to criminal defamation may be classified in three categories: the classical approach; the contemporary (retentionist) human rights-based approach; and the abolitionist approach. The crime of defamation classically developed within a societal structure that is entirely different from the modern egalitarian society. ${ }^{19}$ Under both the Rama and English societies of the sixteenth and seventeenth centuries, social stratification defined relations between and amongst the members of society. ${ }^{20}$ As law was generally, defamation was used to enhance this stratification. Therefore, there was a strong correlation between the defamatory words and the status of the person against whom the words were uttered. ${ }^{21}$ Since society philosophically believed in a divinely-ordained hierarchy, the defamation of an eminent person was regarded as a very serious offence. ${ }^{22}$ Perhaps due to the influence of the Greek philosopher Plato, ${ }^{23}$ it was believed that eminence in society was

18 CR Post 'The social foundations of defamation law: Reputation and the Constitution' (1986) 74 California Law Review 691.

19 Loades (n 15) 141.

20 Veeder (n 14) 546.

21 JC Lassiter 'Defamation of peers: The rise and decline of the action for scandalum magnatum' (1978) 22 American Journal of Legal History 216.

22 Lassiter (n 21) 216.

23 P Westen 'The empty idea of equality' (1982) 95 Harvard Law Review 537. 
attained by quality and those in the lower ranks of society did not have quality. Consequently, when a defamation allegation was made, the enquiry was double-pronged, namely, it was about the words uttered and the quality and the status of the person against whom the words were uttered. This concept is captured aptly by Lassiter as follows: ${ }^{24}$

The offence of defaming eminent persons - specifically peers of the realm had come to be known by the sixteenth century as scandalum magnatum, a medieval Latin expression meaning literally 'the scandal of magnates'. By the seventeenth century, protection from scandalum magnatum had come to be counted regularly among that small body of legal privileges which set the peerage apart from the rest of English society.

Thus, words that ordinarily would be not actionable when uttered against an 'ordinary' person, 'when spoken in disgrace of such high and respectable characters, they amount to an atrocious injury'. ${ }^{25}$ The offence scandalum magnatum has its roots in the statutes of the thirteenth and fourteenth centuries in England. ${ }^{26}$ The flagship statute of this offence was enacted in 1275, and provided: ${ }^{27}$

Whereasmuch as there have been aforetimes found in the country devisers of tales ... whereby discord or occasion of discord hath arisen between the king and his people or great men of this realm ... it is commanded that none be so hardy as to tell or publish any false or tales whereby discord or occasion of discord or slander may grow between the king and his people or the great men of the realm; he doth so shall be taken and kept in prison until he hath brought him the court which was first author.

This classical approach to defamation emerged during the time of unrest when peace and stability, more than equality and freedom, were the fundamental values of society. ${ }^{28}$ Under those circumstances criminal defamation law was used to prevent the circulation of 'bad rumours' and slander against the 'great men of the realm'. ${ }^{29}$ The caste of 'great men of the realm ' included, but was not limited to, 'Prelates, Dukes, Earls, Barons, and great men of the realm, and also of the Chancellor, Treasurer, Clerk of the Privy Seal, Steward of the King's House, Justices of the one bench or the other, and of other great officers of the realm'. ${ }^{30}$

24 Lassiter (n 21) 215. The civil leg of defamation grew from the criminal leg but still was for the peers. As Lassiter comments: 'The peer who was victim of verbal abuse might bring against his abuser an action for scandalum magnatum, stating it to be on behalf of the King as well as himself (tam pro domino rege quam pro se ipso), and alleging damages in a sum sufficient to compensate for the harm done to his reputation as a noble peer of the realm and one of the King's "hereditary" councillors.'

25 W Blackstone Commentaries on the laws of England. Book the Third (1768) 123 (quoted in Lassiter (n 21)).

26 F Carr 'English law of defamation: With especial reference to the distinction between libel and slander' (1902) 18 Law Quarterly Review 255.

273 Edward I, c, quoted in Veeder (n 14) 551.

28 Lassiter (n 21) 217; A Harding A social history of English law (1966).

29 Lassiter (n 21) 217.

30 Veeder (n 14) 553. 
Modern criminal defamation has not been able to outgrow these classical trappings, both theoretically and practically. While the crime of defamation took a slight drift in line with the egalitarian changes in society since the eighteenth century, the vestige of its use in classical times still obtains. The majority of countries now have created the crime of defamation as a crime like any other crime that may be committed against a person regardless of status in society. The purpose of the crime has been couched differently as a protection to reputation, which is an artefact of human dignity. ${ }^{31}$ Nevertheless, there are countries such as Lesotho that still retain the classical crime de scandalum magnatum. Section 79(2) of the Penal Code provides that '[a] person who knowingly commits any act calculated to violate the dignity or injure the reputation of the Royal Family commits an offence'. Even in countries where the scandalum magnatum is not expressly provided for in the statutes, the practice of the prosecution of criminal defamation startlingly resonates with its classic beginnings. The pattern is captured by Leflar as follows: ${ }^{32}$

Modern criminal defamation prosecutions appear on analysis to serve pretty much the same function as the early prosecutions for libel of 'great men'. The usual pattern in the political cases, which are more numerous than any other type of case from 1920 on, is one of the 'ins' prosecuting the 'outs', of the winner prosecuting the loser.

Therefore, in practice, although most countries would feel embarrassed to record it statutorily, the crime of defamation still largely protects 'great men' from 'detractors'. These 'common men' mostly use the media as a conduit for their detractions. Consequently, the media and these 'common men' often become the targets of selective prosecutions. ${ }^{33}$

\subsection{Contemporary (retentionist) human rights-based approach}

There are countries that still retain criminal defamation but have given it a new justification. The new justification is human rights-based. According to this approach, reputation is the bedrock of human dignity and, therefore, must be protected by the defamation laws. The philosophical justification for this 'new approach' is explained by Dworkin who contends that 'the most basic premise of Western democracy - that government should be republican rather than despotic - embodies a commitment to [the] conception of dignity'. ${ }^{34}$ In that sense, defamation laws changed their classical slant where they were inclined towards the protection of the divinely-ordained hierarchy in society and took on the new egalitarian incarnation. They

31 S Hoctor 'Dignity, criminal law, and the Bill of Rights' (2004) 121 South African Law Journal 304.

32 RA Leflar 'Social utility of the criminal law of defamation' (1956) 34 Texas Law Review 9841032.

33 A Stone 'Defamation of public figures: North American contrasts' (2005) $50 \mathrm{New}$ York Law School Law Review 9.

34 R Dworkin Life's dominion (1993) 166-167. 
now take on a new purpose of protecting one of the foundational values of human rights discourse - the right to dignity. ${ }^{35}$ This new justification for defamation laws is best represented by the dictum of the Canadian Supreme Court in the case of Hill $v$ Church of Scientology of Toronto, ${ }^{36}$ where the Court held that good reputation represents an 'innate dignity of the individual, a concept which underlies all the Charter rights. It follows that the protection of the good reputation of an individual is of fundamental importance to our democratic society. ${ }^{37}$

Thus, this new justification locates the reputation of an individual within the ambit of dignity. This formulation has found a comfortable reception in South Africa. ${ }^{38}$ To that end, the South African Supreme Court of Appeal in the case of National Media $v$ Bogoshi ${ }^{39}$ confirmed that human reputation is also an integral value of the South African constitutional project. However, the Court reaffirmed that freedom of expression is an equally important pillar of the South African Bill of Rights. The Court affirmed freedom of expression as 'one of the essential foundations of a democratic society and is one of the basic conditions for its progress and the development of man'.40 These affirmations therefore call for the balance of two equally important values in an open democratic society. As Tocherty observes, ' $[t]$ he pendulum between reputation and expression has swung back and

35 The United States Supreme Court confirmed the inextricability of reputation from dignity in the case of Rosenblatt v Baer 383 US 75 (1966) 97 as follows: 'The right of a man to the protection of his own reputation from unjustified invasion and wrongful hurt reflects no more than our basic concept of the essential dignity and worth of every human being-a concept at the root of any decent system of ordered liberty.'

36 (1986) 26 DLR (4th) 129.

37 Hill case (n 36) 163; see also D Lepofsky 'Making sense of the libel chill debate: Do libel laws "chill" the exercise of freedom of expression?' (1994) 4 National Journal of Constitutional Law 197 contends that reputation is the 'fundamental foundation on which people are able to interact with each other in social environments'; Reynolds v Times Newspapers Ltd [2001] 2 AC 127.

38 In Argus Printing and Publishing v Esselen's Estate 1994 (2) SA 1 (A) 23H-J, the Court quoted with approval the following passage in $\mathrm{M}$ de Villiers The Roman and Roman-Dutch law of injuries (1899) 24-25: 'The specific interests that are detrimentally affected by the acts of aggression that are comprised under the name of injuries are those which every man has, as a matter of natural right, in the possession of an unimpaired person, dignity and reputation.' See also Dawood \& Another $v$ Minister of Home Affairs \& Others 2000 (3) SA 936 (CC).

391998 (4) SA 1196 (SCA).

40 National Media v Bogoshi (n 39) 20. See also Wholesale \& Department Store Union v Dolphinn Delivery (1987) 33 DLR (4th) 183 where the Court stated that '[f]reedom of expression ... is one of the fundamental concepts that has formed the basis for the historical development of the political, social and educational institutions of Western society'. 
forth throughout history'. ${ }^{41}$ In the case of Khumalo $v$ Holomisa ${ }^{42}$ the Court held: 43

The law of defamation seeks to protect the legitimate interest individuals have in their reputation. To this end, therefore, it is one of the aspects of our law which supports the protection of the value of human dignity. When considering the constitutionality of the law of defamation, therefore, we need to ask whether an appropriate balance is struck between the protection of freedom of expression on the one hand, and the value of human dignity on the other.

Informed by this strong human rights justification for the existence of defamation law, the South African Supreme Court of Appeal in Hoho $v$ $S^{44}$ specifically refused to invalidate the crime of defamation and reasoned that the crime still serves a legitimate purpose under the new South African constitutional dispensation. ${ }^{45}$ The Court was persuaded by the same retentionist approach adopted by the Privy Council in Worme $v$ Commissioner of Police of Grenada, ${ }^{46}$ where it was seized of the question of whether the hindrance to freedom of speech under section 10(1) of the Grenada Constitution constituted by the statutory crime of intentional libel was reasonably justifiable in a democratic society. The Privy Council confirmed that '[i]n fact criminal libel, in one form or another, is to be found in the law of many democratic societies, such as England, Canada and Australia. It can accordingly be regarded as a justifiable part of the law of the democratic society in Grenada. ${ }^{47}$

However, despite this retentionist posture, countries such as South Africa are under immense pressure to abolish criminal defamation. ${ }^{48}$

41 B Docherty 'Defamation law: Positive jurisprudence' (2000) 13 Harvard Human Rights Journal 263 267; see also E Brouillet 'Free speech, reputation, and the Canadian balance' (2005) 50 New York Law School Law Review 33.

422002 (5) SA 401.

$43 \quad$ Khumalo $v$ Holomisa (n 42) para 28.

442009 (1) SACR 276 (SCA). In Motsepe v S 2015 (2) SACR 125 (GP) para 40, the North Gauteng High Court went as far as saying: 'Freedom of expression does not have a superior status to other rights under the Constitution. The Constitutional Court has found that freedom of expression must sometimes take a back seat and may be legitimately "chilled" when it intersects with the "foundational" Constitution value of dignity' (emphasis in original).

45 Hoho (n 44) para 36.

46 [2004] UKPC 8.

47 Worme (n 46) para 43.

48 J van der Berg 'Should there be a crime of defamation' (1989) 106 South African Law Journal 276 290; JR Spencer 'Criminal libel: A skeleton in the cupboard' (1977) Criminal Law Review 383; D Milo 'The timely demise of criminal defamation law' 4 October 2015, http://blogs.webberwentzel.com/2015/10/the-timelydemise-of-criminal-defamation-law/ (accessed 1 November 2018); JRL Milton South African criminal law and procedure Vol II: Common law crimes (1996) 520-535; CR Snyman Criminal law (2008) 475-477; J Burchell Principles of criminal law (2006) 741. 


\subsection{Abolitionist wave}

Despite the new-found justification for criminal defamation, countries $^{49}$ and international bodies at large are moving en masse in favour of abolitionism. ${ }^{50}$ The abolitionist movement is based on two main theoretical grounds. The first is that philosophically modern society differs sharply from classical society; the values that undergirded society in classical times have changed. While defamation laws, by and large, originally were intended to protect peace and stability in society, the new philosophical approach embellishes the values of freedom, equality and dignity. The abolitionist movement contends that 'criminal defamation represents the clearest threat ${ }^{51}$ to the values of the modern egalitarian society. Thus, this epochal difference between classical times of criminal defamation and contemporary times provides the strongest reason for jettisoning criminal defamation.

The second reason, which is much more direct, is that freedom of expression has acquired so much prominence in contemporary human rights discourse that the slightest threat to it is visited with the harshest of criticism. ${ }^{52}$ The centrality of freedom of expression to a modern society was flagged in the case of Argus Printing and Publishing $v$ Esselen's Estate ${ }^{53}$ where the Court stressed that 'freedom of expression and of the press are potent and indispensable instruments for the creation and maintenance of a democratic society' ${ }^{54}$ At a more practical level, several aspects of criminal defamation have propelled the abolitionist movement. Van der Berg identifies approximately five reasons why the crime of defamation must be abolished. ${ }^{55}$ The first is the change in the rationale for the offence. The original rationale for the offence was 'the social insecurity of the aristocracy, which increasingly became threatened by the mounting confidence and power of the plebeians' ${ }^{56}$ This argument is located within the broader philosophical drift from classical society to modern society. The second reason is infrequency of prosecutions.

49 Such as Ghana, Kenya and Zimbabwe.

50 International PEN 'Stifling dissent, impeding accountability' 22 November 2017, pensouthafrica.co.za/pen-report-on-criminal-defamation-laws-in-africa/ (accessed 13 November 2018); S Tierney 'Press freedom and public interest: The developing jurisprudence of the European Court of Human Rights' (1998) 3 European Human Rights Law Review 419; EA Berton 'The Inter-American Court of Human Rights and the European Court of Human Rights: A dialogue on freedom of expression standards' (2009) European Human Rights Law Review 332. Herrera Ulloa $v$ Costa Rica (2 July 2004) (Series C No 107); Ricardo Canese v Paraguay (31 August 2004).

51 F Cowell 'The human rights case for libel law reforms in the Commonwealth' (2011) 37 Commonwealth Legal Bulletin 329.

52 E Yanchukova 'Criminal defamation and insult laws: An infringement on the freedom of expression in European and post-Communist jurisdictions' (2003) 41 Columbia Journal of Transnational Law 861.

531994 (2) SA 1 (AD).

54 Argus Printing and Publishing (n 53) para 28.

55 Van der Berg (n 48) 276.

56 Van der Berg 281. 
The incidence of criminal prosecutions is very low across jurisdictions. Hence, in the case of Hoho ${ }^{57}$ the appellant sought to invoke this reason as a ground for striking down the crime. However, the South African Supreme Court of Appeal was unpersuaded and sought support from the Privy Council decision in the case of Worme $v$ Commissioner of Police of Grenada, ${ }^{58}$ where the Court held that '[t] he fact that the law of criminal libel has not been invoked in recent years does not show that it is not needed. After all, prosecutions are in one sense a sign not of the success of a criminal law, but of its failure to prevent the conduct in question. ${ }^{159}$

The third reason is the availability of adequate civil remedies. The civil leg of defamation provides a sufficient or even better remedy than the criminal leg; perhaps this is the reason why there is a paucity of prosecutions for criminal defamation. The flipside of criminal defamation is that often it is amenable to abuse reminiscent of its beginnings as the law protecting the 'great men' ${ }^{60}$ The fourth reason is its questionable effectiveness as a deterrent. ${ }^{61}$ This criticism is located within the perennial debate around the deterrence theory of criminal law. ${ }^{62}$ Hoctor adds two more reasons, the first being the unconstitutionality of the offence. ${ }^{63}$ In most cases, crime struggles to pass constitutional muster. Even where it has barely passed, as in South Africa, the balancing exercise between reputation and freedom of expression still poses a problem. Another reason is the pattern of selective prosecutions. The prosecutions of this crime invariably target political opponents of the establishment.

Although these reasons have propelled the global movement in favour of abolition, the movement is stronger within intergovernmental and international non-governmental formations than within domestic jurisdictions. Many national governments have not yet been persuaded to join the movement. In fact, in Africa, where the crime has been abolished in countries such as in Ghana, ${ }^{64}$

57 Hoho (n 44).

58 As above.

59 Hoho (n 44) para 42.

60 Spencer (n 48) 471 states that '[t]here should be one law for the rich, who can afford to pay damages, and another for the poor, who cannot afford to do so and therefore should be sent to prison'.

61 C Walker 'Reforming the crime of libel' (2005) 50 New York Law School Law Review 169; also see C Walker 'Scandalising in the "eighties"' (1985) 3 Law Quarterly Review 359.

62 Snyman (n 48).

63 S Hoctor 'The crime of defamation: Still defensible in a modern constitutional democracy?' (2013) 34 Obiter 125.

64 O Anku-Tsede 'The media and the offence of criminal libel in Ghana' (2013) 9 Journal of Law, Policy and Globalisation 26. 
Kenya, ${ }^{65}$ Zimbabwe $^{66}$ and Lesotho, ${ }^{67}$ it has not been done through an express policy of government or a legislative repeal of criminal defamation in the statutes. The abolition has been judicial, often after vehement opposition from government. However, the movement has sailed through smoothly at international level. The UN Homan Rights Committee already has called upon state parties to the International Covenant on Civil and Political rights (ICCPR) to 'consider the decriminalisation of defamation'. ${ }^{68}$ Regional human bodies are also active in the movement. The African Commission on Human and Peoples' Rights (African Commission) in 2010 passed a resolution expressly repealing criminal defamation. ${ }^{69}$ In Konaté v Burkina Faso ${ }^{70}$ the African Court on Human and Peoples' Rights (African Court) declared criminal defamation generally in contravention of the African Charter on Human and Peoples' Rights (African Charter). ${ }^{71}$ The pattern is almost the same with respect to other regional courts. ${ }^{72}$ The trend is towards abolition.

65 On 6 February 2017 the High Court of Kenya declared the criminal defamation provision in sec 194 of the Kenyan Penal Code incompatible with Kenya's 2010 Constitution and thus unconstitutional; Jacqueline Okuta \& Another v AttorneyGeneral [2017] eKLR, http://kenyalaw.org/caselaw/cases/view/130781/index .php?id=3479 (accessed 11 November 2018).

66 On 3 February 2016 a full bench of the Zimbabwean Constitutional Court ruled unanimously that criminal defamation was unconstitutional, invalidating sec 96 of the country's Criminal Law (Codification and Reform) Act in the case of Madanhire \& Another v Attorney-General CCZ 2/14.

67 Peta case (n 11).

68 UN Human Rights Committee General Comment 34 of 12 September 2011, CCPR/C/GC/34 para 47, https://www2.ohchr.org/english/bodies/hrc/docs/gc3 4.pdf (accessed 13 November 2018).

69 African Commission on Human and Peoples' Rights 'Resolution on Repealing Criminal Defamation Laws in Africa', http://www.achpr.org/sessions/48th/ resolutions/169/( accessed 29 March 2019).

70 Konaté v Burkina Faso App 4/2013, en.african-court.org/index.php/55-finalisedcases-details/857-app-no-004-2013-lohe-issa-konate-v-burkina-faso-details (accessed 5 November 2018).

71 African Charter on Human and Peoples' Rights adopted in Nairobi, Kenya, 27 June 1981, http://www.humanrights.se/wp-content/uploads/2012/01/African-Charteron-Human-and-Peoples-Rights.pdf (accessed 13 November 2018). Art 9 of the Charter provides: '1) Every individual shall have the right to receive information. 2) Every individual shall have the right to express and disseminate his opinions within the law.' For commentary, see D Shelton 'Konaté v Burkina Faso' (2015) 109 American Journal of International Law 630.

$72 \mathrm{M}$ Pasqualucci 'Criminal defamation and the evolution of the doctrine of freedom of expression in international law: Comparative jurisprudence of the InterAmerican Court of Human Rights' (2006) 39 Vanderbilt Journal of Transnational Law 379. 


\section{Crimes of defamation and scandalum magnatum in Lesotho}

\subsection{Common law and statutory position}

In terms of the common law, the crime of criminal defamation is immensely underdeveloped in Lesotho as there are hardly any reported cases or writings on it. However, it may safely be contended that the South African position is the position in Lesotho, for two reasons. First, the two countries share the common law, which is the Roman-Dutch law. ${ }^{73}$ Second, the South African case law is hugely influential in Lesotho. In South Africa, the question of whether criminal defamation is still part of the South African common law was settled in the case of Hoho. ${ }^{74}$ In this case the appellant sought to attack the crime of defamation on two fronts, namely, that it has been abrogated by disuse and that it was in conflict with freedom of expression as enshrined in the South African Constitution. ${ }^{75}$ The Court categorically refused the claim and endorsed the crime as part of South African common law.

The crime of defamation under common law involves 'the unlawful and intentional publication of matter that impairs another person's reputation'. ${ }^{76}$ The requirements of this crime are fairly settled. These are (a) the unlawfulness, (b) the intention, (c) publication (d) of matter defamatory of (or that impairs) another. ${ }^{77}$ In its classical nature truth was not a defence for the offence, particularly when the 'defamatory and injurious statements were made in a public manner (convicium contra bonos mores)' ${ }^{78}$ However, under modern case law truth as a defence vitiates unlawfulness. ${ }^{79}$ What has been a subject of controversy, though, is whether seriousness (gravity) is a requirement for the crime. In the case of Hoho the Court noted the division in

\section{Pain (n 3) 137.}

74 Hoho (n 44). The Court observed that one of the significant safeguards against the abuse of the crime is that that 'it is ... substantially more difficult to secure a conviction on a charge of defamation than it is to succeed in a civil claim for defamation' (para 33).

75 See sec 16 of the Constitution of the Republic of South Africa, 1996.

76 J Burchell Principles of criminal law (2005) 741; Milton (n 48) 520-535.

77 Hoho (n 44).

78 Veeder (n 14) 564.The essence of the offence in this case lay in the unwarrantable public proclamation, in the contumely that was directed at a man before his fellow citizens. In such cases, the truth of the statements was no justification for the unnecessarily public and insulting manner in which they had been made.

79 The Citizen v McBride 2011 (4) SA 191 (CC). In the case of Khumalo (n 42) para 37, the Court held that ' $[\mathrm{t}]$ he common law delict of defamation does not disregard truth entirely. It remains relevant to the establishment of one of the defences going to unlawfulness, that is, truth in the public benefit. The common law requires a defendant to establish, once a plaintiff has proved the publication of a defamatory statement affecting the plaintiff, that the publication was lawful because the contents of the statement were true and in the public benefit.' 
judicial and scholarly opinion on the question of gravity. ${ }^{80}$ In the end the Court stated that '[i]n the light of these authorities I am not persuaded that the authoritative analysis of the law by Van den Heever JA in Fuleza is wrong and that a degree of seriousness was an element of the crime of defamation in Roman-Dutch law or that it is an element of criminal defamation in our law' ${ }^{81}$

Despite remaining controversial, it would seem that this dictum in the Hoho case is the most recent statement of the common law position as it obtains in South Africa and, arguably, in Lesotho. In Lesotho the statement derives support from one of the most isolated prosecutions on criminal defamation in the country. In 2007 the Crown launched a prosecution for criminal defamation against one Qamaka Nts'ene, a trade unionist, and one Maketso Motjope, a civil servant in the Ministry of Finance. ${ }^{82}$ The particulars of their charge were that they distributed pamphlets accusing the then Prime Minister, Pakalitha Mosisili, and several other cabinet ministers and their spouses of extramarital affairs. The pamphlets also claimed that appointments had been made because of these affairs. The matter was tried in the magistrate's court where the accused were found guilty of criminal defamation. They were sentenced to two years' imprisonment with the option of a two-hundred maloti fine, half of which was suspended for three years. This offence clearly lacked seriousness, but the magistrate's court convicted the accused and imposed a very light sentence.

When the crime was codified under the Penal Code in 2010 seriousness was not included as a requirement. Section 101 of the Penal Code provides that a defamatory matter

means matter likely to injure the reputation of any person by exposing him or her to hatred, contempt of ridicule, or likely to damage the person in his or her profession or trade by an injury to his or her reputation, and it is immaterial whether at the time of the publication of the defamatory matter the person concerning whom the matter is published is living or dead. ${ }^{83}$

80 J van der Berg 'Is gravity really an element of crimen injuria and criminal defamation in our law?' (1988) 54 Journal of Contemporary Roman-Dutch Law 72; FFW van Oosten 'Seriousness, defamation and criminal liability' (1978) 95 South African Law Journal 505; Burchell (n 48) 332-333; Van der Berg (n 48) 276.

81 Hoho (n 44) para 21.

82 M Sithetho 'Lesotho PM sues paper' 2 November 2007, journalism.co.za/lesothopm-sues-paper/ (accessed 10 November 2018). Both persons were opponents of the Prime Ministry from within his own political party, the Lesotho Congress for Democracy, which in the same year experienced a split that resulted in the formation of the All Basotho Convention ( $A B C)$, to which the accused ultimately belonged.

83 Sec 101 of the Penal Code Act 6 of 2010. 
It would seem that the state not only has codified criminal defamation as it existed under common law, but also has expanded it into other aspects that would otherwise not be actionable under common law. ${ }^{84}$ Therefore, the statute has created a completely new offence.

As for scandalum magnatum (offence against the royal family), it is unclear whether it ever really became a crime under Roman-Dutch common law; or whether it ever became part of the common law of Lesotho. The crime has its roots in the English law. Ever since the promulgation of the statutes scandalum magnatum in the thirteenth century ${ }^{85}$ the crime has been part of the English common law. ${ }^{86}$ The crime overtly draws a distinction between 'great men' and 'common men'. As Starkie and Huntington contend, 'words spoken in derogation of a peer or a judge or other great officer of the realm are usually called scandalum magnatum; and though they be such as would not be actionable when spoken of a private person, yet when applied to persons of high rank and dignity, they constitute a more heinous injury'. ${ }^{87}$

The rationale for the crime is that 'there have been oftentimes found in the country devisors of tales whereby discord, or occasion of discord hath many times arisen between the King and his people or great men of the realm' ${ }^{88}$ During codification in Lesotho this crime found its way into the Penal Code. The Code provides that '[a] person who knowingly commits any act calculated to violate the dignity or injure the reputation of the Royal Family commits an offence' ${ }^{89}$ Despite it being so broad in the country, the Code limits the 'Royal Family' to 'the King, the King's nuclear family and the Regent'. 90

84 The requirements of the offence of criminal defamation was narrowly restated in the Hoho case ( $\mathrm{n} 440$ ) para 16 as 'the unlawful and intentional publication of matter concerning another which tends to injure his reputation'. In the case of Peta (n 11) para 18, the Court noted the broad manner in which the section was couched. The Court noted: 'This section is over-broad for the following reasons. In terms of section 102(1) and (2) of the Act criminal defamation prosecution can be initiated even when no person other than the complainant became aware of the supposedly defamatory statement. In terms of this section 102(1) the Act on top of a time-honoured test in defamation matters which is, whether ... the words tend to lower the plaintiff in the estimation of right-thinking members of society has now added a new dimension in terms of which the statement which is heard only by the aggrieved person is considered defamatory. Secondly, in terms of section 102 (2) there is no need for a statement to be completely defamatory to be labelled as such. In my view quite clearly, the means chosen to protect the individuals' reputational interests are broader than necessary to accomplish the said objective.'

85 JC Courtney 'Absurdities of the law of slander and libel' (1902) 36 American Law Review 36 552; RC Donnelly 'The right of reply: An alternative to an action for libel' (1948) 34 Virginia Law Review 867.

86 WL Prosser 'Libel per quod' (1960) 46 Virginia Law Review 839.

$87 \mathrm{~T}$ Starkie \& $\mathrm{T}$ Huntington $A$ treatise on the law of slander, libel, scandalum magnatum and false rumours (1832) 103.

88 As above.

89 Sec 79(2).

$90 \operatorname{Sec} 79(1)$. 
Under common law, there is no reported case on this crime in Lesotho. However, after the codification in 2010 quite a number of 'political detractors' have been prosecuted for the crime. In 2014 the then Minister of Communications, Selibe Mochoboroane, was charged with the crime after a fallout in the coalition government. The Minister belonged to a coalition partner, Lesotho Congress for Democracy (LCD), which was opposed to the prorogation of parliament by the King on the advice of the Prime Minister, Thomas Thabane. ${ }^{91}$ In violation of the principle of collective ministerial responsibility the Minister went on radio on 8 September 2014 and criticised the prorogation. In particular, he said the Prime Minister 'has advised the King to break the law', and was charged with a violation of section 79(2) of the Code. ${ }^{92}$ The charge ultimately was withdrawn by the Director of Public Prosecutions. ${ }^{93}$ In 2017, the same Thomas Thabane was the leader of the opposition in a government led by Prime Minister Pakalitha Mosisili. Ironically, more or less the same set of facts that led Mochoboroane to be charged also led to Thabane being charged with the same offence. As a leader of opposition Thabane was opposed to the dissolution of parliament which the King was going to effect on the advice of the Prime Minister (Mosisili) in 2017. Thabane said that the King was younger than him and that he hoped that he would do the right thing and refuse the advice for dissolution and early elections. He also indicated that the King was not irremovable, and that he, too, may be removed from his position. Thabane was charged with the same section $79(2) .{ }^{94}$ The case was again withdrawn when Thabane became the Prime Minister after the 2017 election.

In a similar manner, another opposition activist, Bokang Ramats'ella, has been a victim of the same section. He was charged in 2017 after his coalition had lost the election. ${ }^{95}$ Ramats'ella allegedly went on radio and said that the All Basotho Convection party (the ruling party) had dragged the King into politics. He said that the King

$91 \mathrm{H}$ Nyane 'The advent of coalition politics and the crisis of constitutionalism in Lesotho' in M Thabane (ed) Towards anatomy of political instability in Lesotho, 1966-2016 (2017) 77.

92 K Mohloboli 'Mochoboroane faces sedition charge' Lesotho Times 13 November 2014, http://www.lestimes.com/mochoboroane-faces-sedition-charge/(accessed 15 November 2018).

93 T Tefo 'Mochoboroane defiant after court victory' Lesotho Times 20 November 2014, http://www.lestimes.com/mochoboroane-defiant-after-court-victory/ (accessed 15 November 2018).

94 T Tefo 'Thabane faces sedition charge' Lesotho Times 7 April 2017, www.lestimes.com/thabane-faces-sedition-charge/ (accessed 15 November 2018); T Tefo 'Drama in court during Thabane case' Lesotho Times 7 April 2017, http:// www.lestimes.com/drama-in-court-during-thabane-case/ (accessed 15 November 2018).

95 'Ramatsella's case still under consideration' TMGLive 11 July 2017, https:// tmglive.tv/2017/07/ramatsellas-case-still-consideration/ (accessed 15 November 2018). 
should 'refrain from engaging in politics regardless of whether he supports the opposition or government'. ${ }^{96}$

These post-Code scandalum magnatum cases clearly demonstrate that the crime is used to silence dissent and criticism. In most of these cases the criticism was not even directly against the King, but was against the Prime Minister who happened to be his adviser constitutionally.

\subsection{Partial abolition: Peta v Minister of Law, Constitutional Affairs and Human Rights}

An occasion arose in 2018 in the case of Peta ${ }^{97}$ for the constitutionality of criminal defamation to be tested. As in most criminal defamation cases, the case arose out of political circumstances. It arose out of the highly-charged political atmosphere prevailing in June 2016 when the international community was exerting substantial pressure on the government of Lesotho to relieve the then commander of the Lesotho defence force, Tlali Kamoli, of his duties as commander. This followed recommendations by the Southern African Development Community (SADC) commission of inquiry. ${ }^{98}$ The government of Lesotho resisted the pressure ${ }^{99}$ and the newspaper Lesotho Times satirised the entire scenario. ${ }^{100}$ The accused was the editor of the Lesotho Times that had published the satire article. The article satirised the then all-powerful commander as having put the cabinet under siege. It portrayed Kamoli as having entered a cabinet meeting unannounced and ordering the chairperson of the meeting, the Prime Minister, to stop the proceedings, and the Prime Minister dutifully obliged. The satire stated: 'The reason for ... Kamoli doing all this ... was because he wanted to show who indeed was the mighty King of this country. He wanted to prove where real power resided. ${ }^{\prime 101}$ The reality of the matter is that the satire was depicting the general feeling in society

96 T Tefo 'Ramatsella faces charges for remarks' Lesotho Times 17 February 2017, www.lestimes.com/ramatsella-faces-charges-for-remarks/ (accessed 15 November 2018).

97 Peta case (n 11).

98 Communiqué, Double Troika Summit of SADC Heads of State and Government, Gaborone, Botswana, 18 January 2016 (issued 19 January 2016), http://www. sadc.int/files/7014/5322/7325/Communique_19_Janauary_2016_-_0950hrs.pdf (accessed 13 November 2018).

99 See M Mohloboli 'Mosisili defiant over SADC report' Lesotho Times 22 January 2016, http://lestimes.com/mosisili-defiant-over-sadc-report/ (accessed 15 October 2018); M Mohloboli 'Kamoli here to stay: LCD' Lesotho Times 14 May 2016, www.lestimes.com/kamoli-here-to-stay-lcd/ (accessed 15 October 2018).

100 Lesotho Times 23-29 June 2016.

101 Scrutator 'Flicker of hope for my beloved kingdom' Lesotho Times 23-29 June 2016. 
and that at the time General Kamoli appeared very powerful in the country. ${ }^{102}$ On the basis of strict liability, ${ }^{103}$ the accused was charged with criminal defamation in terms of section 104 of the Penal Code. The accused challenged the constitutionality of the criminal defamation sections of the Code, namely, section 104 read with sections 101 and $102 .^{104}$ The mainstay of his case was that the sections contravened section 14 of the Constitution of Lesotho which embodies freedom of expression. The section contains unusually extensive special limitation clauses. The internal limitation clauses in section 14 of the Constitution stipulated almost everything as a permissible limitation of the right to freedom of expression. Any law that makes provision for the following is regarded as permissible: 105

the interests of defence, public safety, public order, public morality or public health; or (b) for the purpose of protecting the reputations, rights and freedoms of other persons or private lives of persons concerned in legal proceedings, preventing the disclosure of information received in confidence, maintaining the authority and independence of the courts, or regulating the technical administration or the technical operation of telephony, telegraphy, posts, wireless broadcasting or television; or (c) for the purpose of imposing restrictions upon public officers.

Clearly, these limitations constitute claw-back clauses rather than real limitation clauses. ${ }^{106}$ However, the Court found a way of invalidating criminal defamation notwithstanding such a laborious web of limitations on the right to freedom of expression. The Court used the abolitionist theory as flagged in the decision of the African Court in

102 'Too risky to arrest Lesotho coup leader' - Report' News24 14 September 2014, https://www.news24.com/Africa/News/Too-risky-to-arrest-Lesotho-coup-leaderreport-20140914 (accessed 15 March 2019); 'Lesotho army chief accused of 2014 coup attempt resigns' 11 September 2016, https://www.news24.com/Africa/ News/lesotho-army-chief-accused-of-2014-coup-attempt-resigns-20161108 (accessed 15 March 2019).

103 Strict liability of newspaper editors is part of Lesotho's common law of defamation. See the case of Mosisili v Editor, Mirror Newspaper \& Others CIV/T/275/ 2001, https://lesotholii.org/ls/judgment/high-court/2008/62 (accessed 25 April 2019). The decision followed older South African cases such as Pakendorf $v$ De Flamingh 1982 (3) SA 146 (A); Suid-Afrikaanse Uitsaaikorporasie v O'Malley 1977 (3) SA 394, whereas in National Media v Bogoshi 1998 (4) SA 1196 (SCA), the South African Constitutional Court ruled strict liability unconstitutional.

104 Sec 102 provides: '(1) A person publishes a defamatory matter if he or she causes the print, writing, painting, effigy or other means by which the defamatory matters is conveyed to be dealt with, either by exhibition, reading, recitation, description, delivery or otherwise, so that the defamatory meaning thereof becomes known or is likely to become known to either the person defamed or any other person. (2) It is not necessary for defamation that a defamatory meaning should be directly or completely expressed, and it suffices if such meaning and its application to the person alleged to be defamed can be collected either from the alleged defamation itself or from any extrinsic circumstances, or partly by the one and other means.'

$105 \mathrm{Sec}$ 40(2).

106 For an analysis of claw-back clauses in the African Charter on Human and Peoples' Rights, see R Gittleman 'The African Charter on Human and Peoples' Rights: A legal analysis' (1982) 22 Virginia Journal of International Law 667; C Heyns 'The African regional human rights system: In need of reform?' (2001) 1 African Human Rights Law Journal 155. 
Konaté $v$ Burkina Faso ${ }^{107}$ which it called 'a landmark judgment'. 108 The Court also relied heavily on international decisions and resolutions, ${ }^{109}$ and decisions of other foreign jurisdictions that are on the abolitionist bandwagon. ${ }^{110}$ In the end, the Court used the proportionality test which now is fairly established in human rights litigation in Lesotho. ${ }^{111}$ The Court found that ' $[\mathrm{t}]$ he means used to achieve the purpose of protecting reputation interests, in some instances, are overbroad and vague in relation to the freedom of expression guarantee in section 14 of the Constitution'.112 The decision has been widely welcomed as a step in the right direction, not only for affirmation of freedom of expression in the country but even for human rights generally in Lesotho. The human rights provisions in the Lesotho Constitution are overwhelmed by claw-back clauses under the guise of special limitation clauses. ${ }^{113}$ However, while the abolition of criminal defamation is lauded, it is only partial because other 'insult offences' remain on the Penal Code. ${ }^{114}$

It is important to note that while the decision in Peta has established Lesotho on the list of countries where criminal defamation has been abolished, care must be taken when invoking the case as persuasive authority in other jurisdictions such as South Africa. The Court in Peta specifically invalidated the statutory provisions of a specific jurisdiction, Lesotho. ${ }^{115}$ The case may not be a safe authority for countries that still use the common law position such as South Africa. In any event, the South African Supreme Court of Appeal in the Hoho case already has pronounced that crimen injuria is not unconstitutional. ${ }^{116}$ Perhaps a route that may remain for countries such as South Africa is to pass an Act of parliament categorically abolishing the crime of defamation.

107 Konaté (n 70); Shelton (n 71) 630.

108 Konaté (n 70) para 21.

109 African Commission Resolution 169 (n 69).

110 Konaté (n 70); Okuta (n 65); Madanhire (n 66).

111 Attorney-General v 'Mopa (2002) AHRLR 91 (LeCA 2002); Commander of Lesotho Defence Force $v$ Rantuba LAC (1995-99) 687. The cases that use the proportionality test in Lesotho follow the three-pronged test devised by Dickson CJ in $R v$ Oakes [1986] 1 SCR 103 as follows: '(i) Firstly, the measure limiting the right or freedom must be rationally connected to achieve that purpose. (ii) Secondly, the measure, even if rationally connected to the objective should impair "as little as possible" the right or freedom under the spotlight. (iii)Thirdly, there must be proportionality between the effects of the measure limiting the right or freedom and the purpose which has been classified as of sufficient importance.'

112 Peta (n 11) para 24.

$113 \mathrm{H}$ Nyane 'Limitation of human rights under the Constitution of Lesotho and the jurisprudence of superior courts' (2015) 23 Lesotho Law Journal 1.

114 See secs 78 \& 79 of the Penal Code Act 6 of 2010.

115 Lesotho's entire criminal law has been codified. Sec 2(2) of the Penal Code Act 6 of 2010 provides that '[n]o person shall be tried, convicted or punished for an offence other than an offence specified in this Code or in any other written law or statute in force in Lesotho'.

116 Hoho (n 44). 


\section{Conclusion}

The article set out to investigate the ramifications of the abolition of criminal defamation in Lesotho. It is apparent from the foregoing that the crime of defamation dates back to the late nineteenth century when the country was removed from the administration of the Colony of the Cape of Good Hope. ${ }^{117}$ However, the crime has not been used in Lesotho as there are no reported cases of criminal defamation in the country. The most prominent occasion when the crime was prosecuted was in 2007 when the magistrate's court for the District of Maseru found two people guilty of this crime for having 'defamed the then Prime Minister, Mosisili'. ${ }^{118}$ The disuse notwithstanding, ${ }^{119}$ the crime formerly was part of Lesotho's criminal law until 2010 when the Penal Code was enacted. The Code provides that '[n]o person shall be tried, convicted or punished for an offence other than an offence specified in this Code or in any other written law or statute in force in Lesotho'. ${ }^{120}$ Even in the aftermath of codification the crime continued to be used to prosecute detractors of government until 2018 when the crime was judicially abolished. The contention raised throughout the article has been that as long as scandalum magnatum and other 'insult crimes' remain on the statute books the abolition of criminal defamation is only the tip of an iceberg. ${ }^{121}$ In fact, the possibility is that in future prosecutions based on other insult crimes, such as crimen injuria, ${ }^{122}$ sedition $^{123}$ and scandulum magnatum ${ }^{124}$ will rise in order to make up for the abolition of criminal defamation. This

117 Proclamation 2B of 1884 .

118 Sithetho (n 82).

119 In Hoho (n 44) para 14 the Court observed: 'I have not been able to find and we have not been referred to any suggestion by an academic or anybody else, before this case, that criminal defamation has been abrogated by disuse.'

120 Sec 2(2).

121 See BT Balule 'Insult laws: A challenge to media freedom in the SADC's fledgling democracies?' (2008) 41 Comparative and International Law Journal of Southern Africa 404.

122 Sec 104.

123 See sec 76. In 2014 when Mochoboroane was charged with criminal defamation, the alternative charge was sedition. He was charged with a contravention of sec 76(2)(b) read with sub-secs (1) and (5)(a), (b), (c), (d), and (e) of the Penal Code Act 6 of 2010. The particulars of the alternative charge were the following: '[T]he said accused unlawfully and with the intention of defying or subverting the authority of the Government of Lesotho, but without the intention to overthrow or coerce the Government of Lesotho, did utter seditious words to wit ... leha se re tlohela ho e sheba mahlong a molao ke bona mona Tona-Kholo a elelitse Motlotlehi ho tlola molao are o sebelisa molao to bring into hatred or contempt or to excite disaffection against the person of His Majesty or the Government of Lesotho ... or to incite the people and residents of Lesotho ... and/or to bring into hatred or contempt or to excite disaffection against the administration of justice in Lesotho ... or to cause discontent or disaffection against the administration of justice in Lesotho ... and/or to promote feelings of ill-will and hostility between different classes of the population of Lesotho.' This alternative charge only evinces the argument made in this article that now that criminal defamation has been abolished, governments in Lesotho will easily use sec 76 against detractors.

$124 \mathrm{Sec} 79$. 
possibility is also strengthened by the fact that the country has a very weak Bill of Rights. The Bill of Rights under the Constitution of Lesotho is virtually engulfed in the web of claw-back clauses disguised as special limitation clauses. ${ }^{125}$

As such, the country may have to undergo a comprehensive review of the laws hampering the full realisation of freedom of expression, including the Constitution. It is recommended that all 'insult criminal laws' be repealed and the structure of limitation clauses in the Constitution be reviewed. The model of one general limitation clause for all the human rights provisions is recommended. ${ }^{126}$ Special limitation clauses may be used sparingly depending on the nature of the right involved.

The article also notes that by abolishing criminal defamation Lesotho has joined an emerging global movement in favour of decriminalisation. This may encourage other countries to follow suit. However, a caution has been raised here that while Lesotho has codified its criminal law, other countries have not. Common law, which is the springboard for criminal defamation, continues to be part of the criminal law in countries such as South Africa. ${ }^{127}$

125 Nyane (n 113) 1.

126 See sec 36 of the South African Constitution. It must be noted, however, that contrary to the widely-held view that the Constitution of Lesotho does not have a general limitation clause, sec 4(1) has vaguely couched 'general limitation clause' as follows: 'The provisions of this Chapter shall have effect for the purpose of affording protection to those rights and freedoms, subject to such limitations of that protection as are contained in those provisions, being limitations designed to ensure that the enjoyment of the said rights and freedoms by any person does not prejudice the rights and freedoms of others or the public interest.'

127 Milton (n 48) 519. 